\title{
A NEW GENUS OF AGENIELLINI FROM CENTRAL AMERICA (HYMENOPTERA: POMPILIDAE: PEPSINAE)*
}

\author{
By Marius S. Wasbauer \\ Analysis and Identification/Entomology \\ California Department of Food and Agriculture \\ Sacramento, California 95814
}

The spider wasp tribe Ageniellini is a diverse and successful group in the new world. The Nearctic species are assignable to three genera, Phanagenia Banks, 1933, Auplopus Spinola, 1841 and Ageniella Banks, 1912. None of these genera is restricted to the Nearctic Region.

Phanagenia comprises African and Oriental species as well as a single Nearctic representative. Auplopus is cosmopolitan with a number of species in temperate and tropical America. Ageniella is restricted to the New World. It is the largest genus of the tribe in North America with thirty-six species reported from north of the Mexican border. The Nearctic species of Ageniella have been placed in four subgenera (Townes, 1957) and the Neotropical species in seven, four of them confined to the neotropics (Evans, 1973). I do not consider the subgenus Ameragenia with representatives in extreme southern Texas and Florida to be a Nearctic element. Although figures are not available, there are probably more species in the Central and South American segment of the Ageniella fauna than in the North American.

In addition to Auplopus and Ageniella there are five additional genera in the neotropics, Phanochilus Banks, 1944, Priocnemella Banks, 1925, Mystacagenia Evans, 1973, Dimorphagenia Evans, 1973 and the genus described below, which are all apparently confined to that region.

An explanation of the abbreviations used in the following descriptions is given by Wasbauer and Kimsey (1985:4) and is summarized here.

*Manuscript received by the editor March 25, 1987. 
FD-facial distance. The length of the head in full frontal view, from the crest of the vertex to the apex of the clypeus.

LID-lower interocular distance. The minimum distance between the lower margins of the compound eyes.

MID-middle interocular distance. The maximum distance between the inner margins of the compound eyes.

OOL-ocellocular length. The minimum distance between the outer margin of the lateral ocellus and the inner margin of the compound eye.

POL-postocellar length. The minimum distance between the inner margins of the lateral ocelli.

TFD-transfacial distance. The maximum distance across the head from the outer margin of one compound eye to the outer margin of the other.

UID-upper interocular distance. The minimum distance between the upper margins of the compound eyes.

Atopagenia Wasbauer, new genus

Female. Large wasps, the size of small Pepsis. Head (fig. 1) with clypeus very long and wide, extending laterally well under compound eyes, anterior margin strongly gibbous; malar space well developed; apex of mandibles broad, tridentate (including apical cusp); mentum with a number of long, slender, dark hairs; palpi long, maxillary palpi extending beyond apex of anterior coxa; labrum not exposed in anterior view, its apex truncate; occipital carina extending dorsally onto vertex in a short loop. Mesosoma with disc of pronotum gently sloping anteriorly to a small, rounded, median dorsal projection; postnotum scarcely developed, very short, not expanded at midline; mesosternum with posterior carina sharply angled laterally; wings long, extending beyond apex of metasoma, anterior wing with marginal and submarginal cells approaching wing apex; first recurrent vein meeting second submarginal cell close to its apex; posterior wing with anal vein in an even curve, meeting discoidal vein beyond origin of cubitus; tibial spurs short, those at apex of posterior tibia of nearly equal length; anterior tibia without noticeable spines except short, slender spines at apex, without stout, curved spine at outer apex; posterior tibia smooth with unbroken dorsal carina extending nearly to apex; posterior basitarsi somewhat arched 
dorsally; distitarsi without ventral spines; claws toothed. Metasoma with first segment of typical agenioid form in dorsal view, sides concave, expanded at insertion on mesosoma, in lateral view without a suture separating an epipleurum; second sternum with transverse suture in extreme anterior position, connate medially with posterior margin of first sternum; pygidial area undifferentiated, dull, densely clothed with long, uniformly fine setae.

Male. Similar to female in most details, but head with clypeus and occipital carina unmodified; apex of labrum exposed in frontal view; mandibles slender, bidentate; anterior tibial spur barely exceeding apex of tibia; anterior and middle legs with distitarsi longer than preceding three segments taken together. Metasoma with first sternum convex; second sternum swollen anteriorly, swelling bordered posteriorly by curved, deeply impressed transverse groove; apical margin of sixth sternum (fig. 3) with large, rectangular emargination and paired apical spines; genitalia (fig. 4) with aedeagus bearing pair of accessory apodemes; basal hooklets single.

Type species. Atopagenia menkei Wasbauer, new species.

Etymology. Gr.: Atopos-odd or strange; agenia-beardless.

Atopagenia menkei Wasbauer, new species.

Holotype female. Black with faint blue to violet reflections imparted by appressed pubescence; small spots under compound eyes, apex of clypeus and apex of mandibles, ferrugineous. Length $29 \mathrm{~mm}$. Anterior wing length $31 \mathrm{~mm}$; both pairs uniformly dark to apex with strong violaceous reflections. Erect hair black, long, fine and abundant over most of body, absent on following areas: mesonotum, except for a few scattered hairs anteriorly, femora dorsally, anterior and middle tibiae and tarsi, the latter with a few short hairs dorsally, first metasomal tergum except at apex. Appressed pubescence dense, fine and dark on head and mesosoma, imparting a dull, velvety appearance, more dilute on somewhat shining metasoma. Head (fig. 1) rounded, about as wide as long, FD/TFD 1.05; ocelli forming a compact right triangle, laterals much closer to each other than to compound eyes, POL/OOL 0.57; front moderately narrow, MID/TFD 0.56; compound eyes nearly parallel, LID/UID 0.95 ; length of clypeus 0.59 times its width, apical margin strongly convex; length of malar space 0.56 width of mandible at base; antennae very long, slender, third segment 10.8 times as long as 

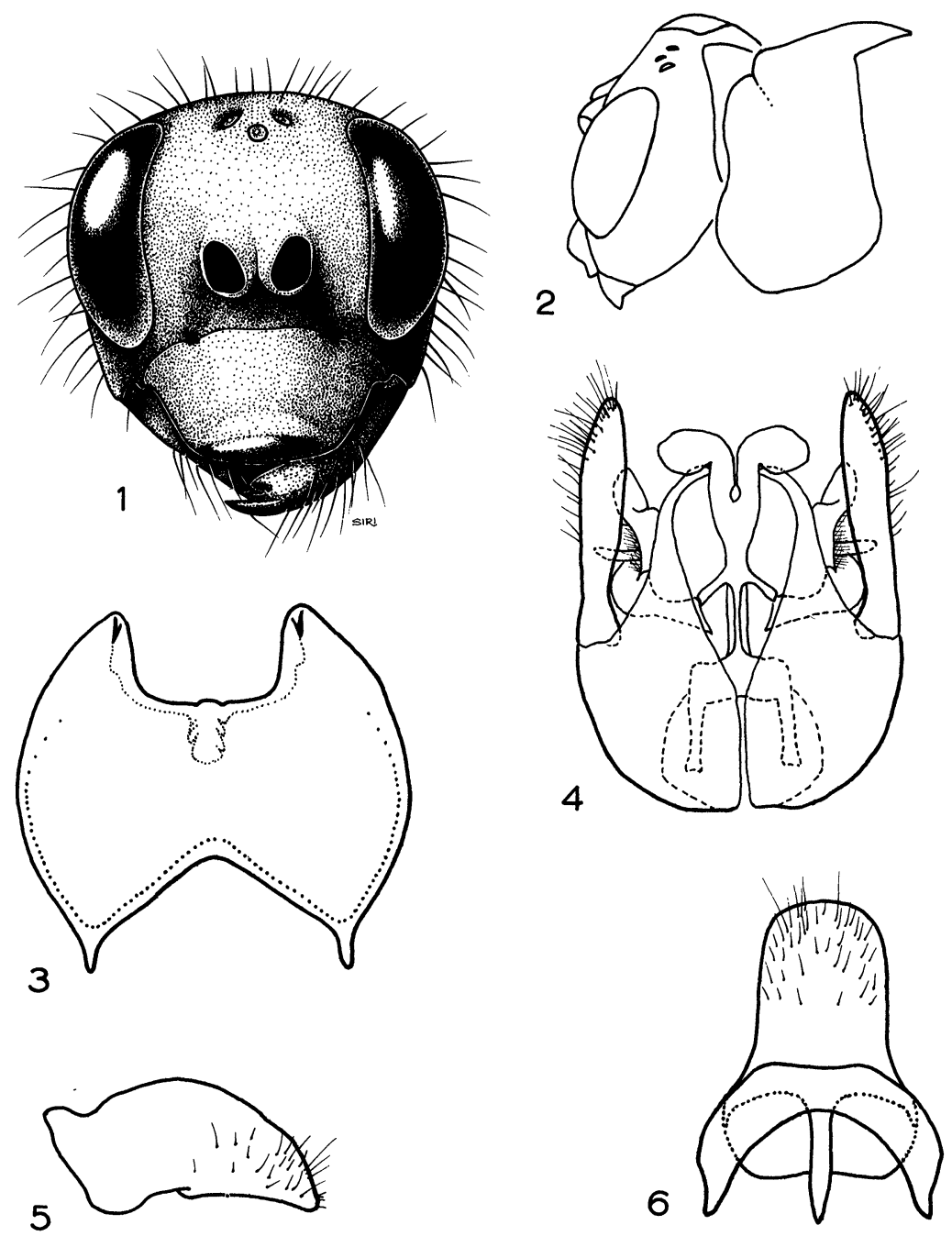

Figs. 1-6. Atopagenia menkei, n. sp. Figs. 1-2. Holotype female. Figs. 3-6. Allotype male. Fig. 1. Head, anterior view. Fig. 2. Outline of head and pronotum, oblique lateral view. Fig. 3. Sixth metasomal sternum, ventral view (not flattened, vestiture omitted). Fig. 4. Genitalia, dorsal view. Fig. 5. Left gonostylus, lateral view. Fig. 6. Subgenital plate, ventral view. 
wide, 1.43 times UID, apical segment 9.4 times as long as wide. Pronotum (fig. 2) with collar not much below level of disc, separated from anterodorsal projection by short concave face, posterior margin broadly angulate; mesepisternum not produced; propodeum short, slope even from front to rear, faintly striate with shallow median sulcus anteriorly; area laterad of spiracle produced into distinct tubercle; posterior tibiae and tarsi very hairy; brush on inner side of hind tibia complete, broad at base, narrowed toward apex; distitarsi very long, length of posterior distitarsus (excluding claws) 3.9 times its apical width; tarsal claws large with small, erect, basal tooth; anterior wing with stigma small; marginal cell 5.4 times as long as high, 0.38 times its length from apex of wing; third submarginal cell 2.12 times as high at apex as at base, 1.19 times as long as second submarginal, measured on cubitus; third transverse cubital vein curved before junction with cubitus; transverse median vein meeting media 0.46 of its length distad of basal vein; second recurrent vein meeting third submarginal cell at about middle and joining subdiscoidal vein 0.77 times the distance from base of discoidal to its intersection with wing margin.

Allotype male. Similar to female in color and pilosity, but without ferrugineous spots on face and clypeus. Length $18.0 \mathrm{~mm}$. Anterior wing $18.3 \mathrm{~mm}$. Head thin, temples not developed, slightly wider than long, FD/TFD 0.89; ocelli in a compact triangle, $\mathrm{POL} / \mathrm{OOL}$ 0.56 , posterior ocelli in a line with posterior corners of compound eyes; MID/TFD 0.62; compound eyes nearly parallel as in female; length of clypeus 0.49 times its width, apical margin slightly convex; antennae long and slender, third segment 6.25 times as long as wide, 1.10 times UID, apical segment 8.3 times as long as wide. Pronotum and mesepisternum as in female; postnotum short, 0.35 times as long as metanotum, transversely striate; propodeum less strongly curved, but striate as in female; wing color and venation as in female; posterior tibia and tarsi not hairy; tibia with unbroken dorsal carina as in female, but with dorsal row of slender curved spines; tarsal segments, except distitarsus laterally compressed, distitarsi long, that of posterior leg 5.3 times as long as apical width. Sixth metasomal tergum large; subgenital plate (fig. 6) broad, ligulate, flat, rounded at apex; genitalia with gonostylus attenuate at apex (fig. 5); parapenial lobes strongly curved toward midline; aedeagus expanded beyond middle and produced into pair of large, flattened, horizontal lobes at apex (fig. 4). 
Type material. Holotype female (LACM): Costa Rica: Golfito, August 21, 1957 (Arnold Menke). Allotype male (LACM) and paratypes ( 1 female, 3 males, USU and author's collection): Panama: Canal Zone: Gamboa, 5 mi SE, March 1, 1959 (W. J. Hanson). According to Mr. Hanson's field notes, the allotype and paratypes were collected near a military access road through an area of rain forest which had been cut over, but had developed a subsequent overstory.

Remarks. Atopagenia appears to be only distantly related to other genera in the Ageniellini. The form of the female occipital carina and the pronotum of both sexes apparently is apomorphic in the tribe. There are at least some similarities to the Old World genus Macromeris in size, color and pilosity (especially of the legs), presence of a definite malar space, long antennae and retention in the male of the transverse groove on the second sternum. Other fundamental features of Macromeris are quite different, however. The first metasomal segment has a suture separating an epipleurum, the transverse groove on the second sternum of the female is not in an extreme anterior position, the anal vein of the posterior wing is strongly recurved, the pygidium of the female is noticeably differentiated, nearly bare and the basal hooklets of the male genitalia are double.

Because of the densely hairy ultimate tergum of the female, it is unlikely that Atopagenia menkei constructs cells of mud or similar materials as do females of at least some species of Macromeris and Auplopus (Williams, 1919: 79), but one is tempted to speculate that the unusual modification of the occipital carina and pronotum are adaptations for prey capture in confined situations.

Acknowledgements. I wish to express my thar.ks to Mr. Roy R. Snelling, Los Angeles County Museum (LACM) and to Dr. Terry Griswold, USDA, ARS, Logan, Utah for providing the material used here. Thanks are also due Mr. William J. Hanson, Department of Biology, Utah State University, Logan (USU) for providing notes on the Panama locality. Mr. Michael C. Day, Department of Entomology, British Museum (Natural History), London, kindly compared specimens with Cameron's material in the British Museum. Drs. Howard E. Evans, Colorado State University, Ft. Collins and Lynn S. Kimsey, University of California, Davis reviewed and made suggestions on the manuscript. In addition, Dr. Kimsey executed one of the drawings (fig. 1). 


\section{SUMMARY}

A new genus and species of spider wasp, Atopagenia menkei is described in the pepsine tribe Ageniellini based on both sexes from Costa Rica and Panama. A brief discussion is given of the other new world genera in the tribe.

\section{Literature Cited}

BANKS, N.

1912. Psammocharidae: classification and descriptions. Jour. New York Entomol. Soc., 19: 220-237.

1925. Psammocharidae from Panama. Bull. Mus. Comp. Zool., 67: 329-338.

1933. New Psammocharidae from the United States. Psyche, 40: 1-19.

1944. Psammocharidae (Hymenoptera) taken at Kartabo and other localities in British Guiana. Zoologica, 29: 97-112.

Evans, H. E.

1973. Studies on Neotropical Pompilidae (Hymenoptera). IX. The genera of Auplopodini. Psyche, 80: 212-226.

SPINOLA, M.

1841. Hyménoptères recueillis a Cayenne en 1839 par M. Leprieur, pharmacien de la Marine Royale. Seconde partie. Ann. Soc. Entomol. France, 10: $85-149$.

TOWNES, $\mathrm{H}$.

1957. Nearctic wasps of the subfamilies Pepsinae and Ceropalinae. Bull. U.S. Natl. Mus., 209: 1-286. 4 pl.

WASBAuer, M. S. AND L. S. KimseY

1985. California spider wasps of the subfamily Pompilinae (Hymenoptera: Pompilidae). Bull. Calif. Insect Surv., 26: 130 pp., 13 pl.

Williams, F. X.

1919. Philippine wasp studies. Part 2. Descriptions of new species and life history studies. Hawaiian Sugar Planters' Association. Exper. Sta. Bull. (Entomol. Ser.), 14: 20-186. 

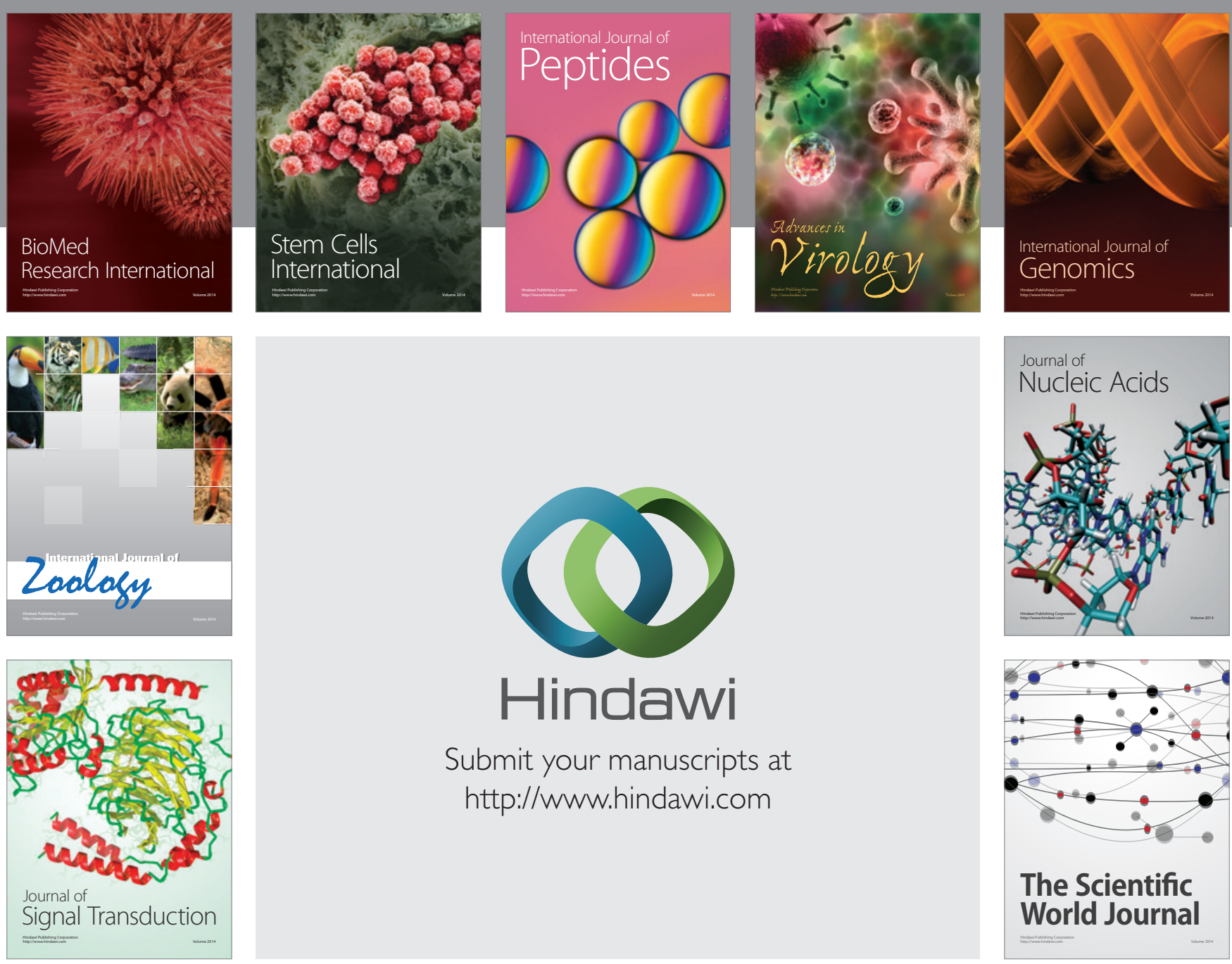

Submit your manuscripts at

http://www.hindawi.com
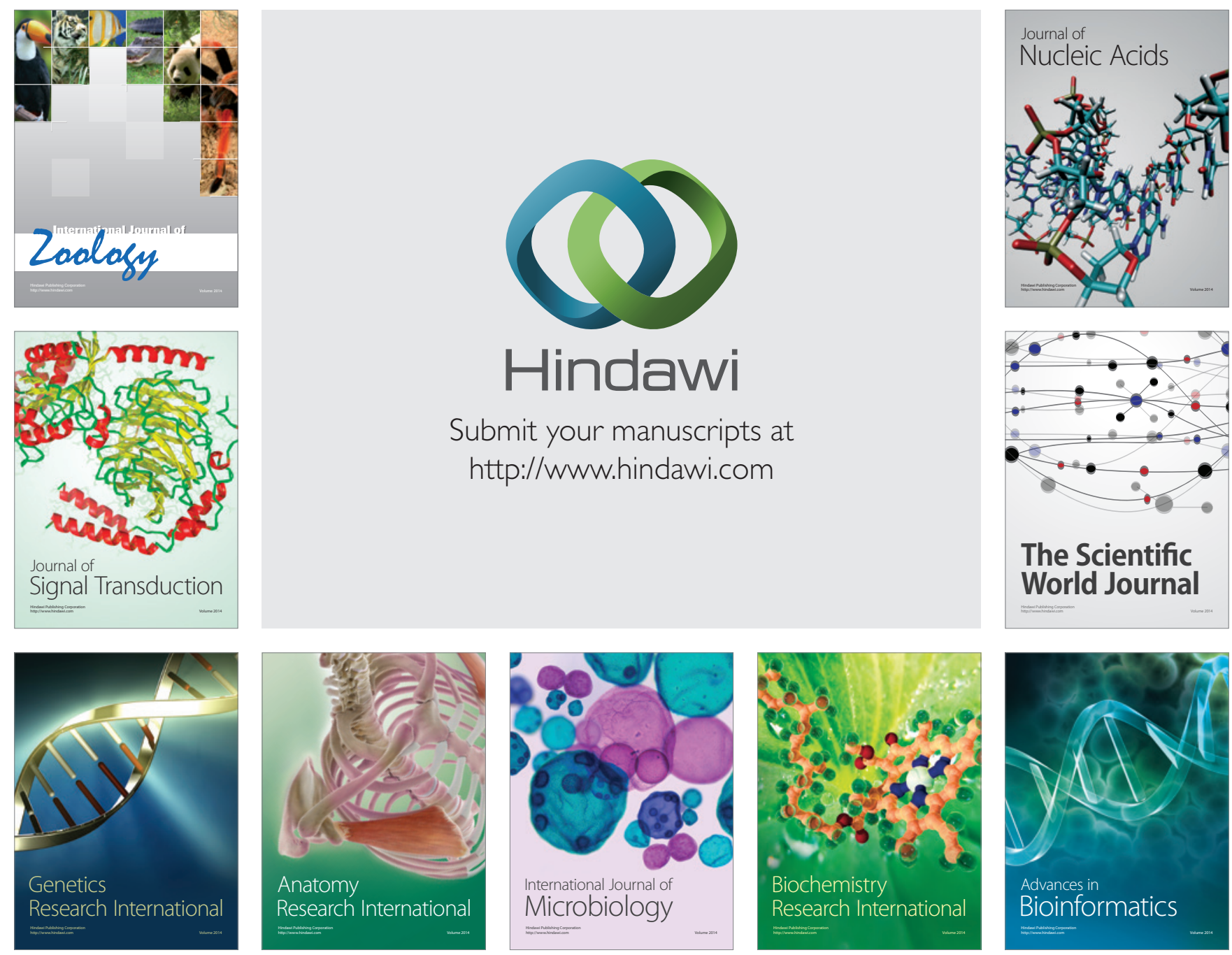

The Scientific World Journal
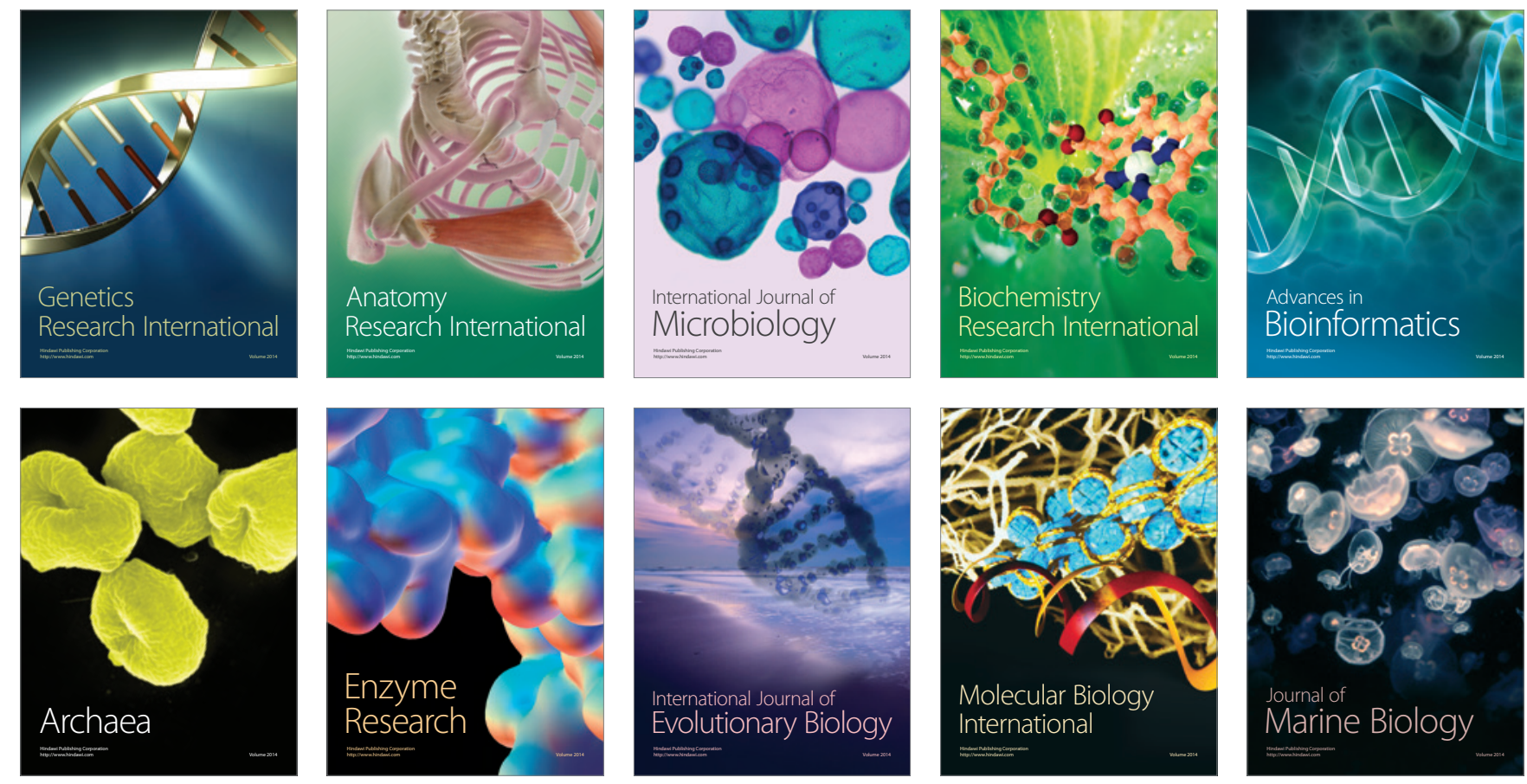